\title{
TINJAUAN HUKUM PIDANA TERHADAP TINDAK PIDANA BERITA BOHONG DAN UJARAN KEBENCIAN DI MEDIA SOSIAL
}

\author{
Enik Isnaini, Munif Rochmawanto, Jatmiko Winarano, \\ enikisnaini354@gmail.com, jatmiko.unisla@gmail.com
}

\section{Universitas Islam Lamongan}

\begin{abstract}
ABSTRAK
Terhadap perbuatan hoaks dan ujaran kebencian tidak hanya diatur oleh hukum positif (hukum yang berlaku di Indonesia) saja, namun juga diatur oleh perjanjian/konvensi internasional. Sedangkan unsur dari perbuatan hoax dan ujaran kebencian termasuk dalam kategori sifat melawan hukum yang mana dalam hukum pidana juga dibenarkan hal tersebut berdasarkan peraturan perundang-undangan pidana yang berlaku terhadap perbuatan hoax dan ujaran kebencian. Dari penjelasan di atas, Brigjen Rikwanto menuturkan adanya beberapa peraturan hukum yang dapat menjerat perbuatan hoax maupun ujaran kebencian serta menjelaskan harus adanya korban atau pihak yang merasa dicemarkan nama baiknya dari perbuatan hoax atau ujaran kebencian berdasarkan penilaian subyektifnya.
\end{abstract}

Kata Kunci : Ujaran Kebencian, Berita Bohong, Hukum Pidana

\section{PENDAHULUAN}

Dewasa ini seringkali dijumpai bermacam-macam kasus yang terjadi, khususnya di media elektronik. Perlu diketahui, bahwa perkembangan teknologi yang semakin canggih serta perubahan yang terjadi di bidang teknologi informasi yang dinamis mendorong pula pada sikap dan perbuatan manusia untuk berubah mengikuti perkembangan teknologi informasi yang dinamis. Media teknologi informasi membuat semakin mudahnya seseorang untuk berinteraksi terhadap satu sama lainnya, bahkan tidak memberikan batasan-batasan atau dengan kata lain tidak hanya ruang individu (antar personal) saja, namun juga ruang publik.

Ada beberapa aspek yang mendorong pemerintah agar menetapkan kebijakan perihal teknologi informasi, yaitu dengan diberlakukannya Undang-Undang Nomor 19 Tahun 2016Tentang Informasi \& Transaksi Elektronik. Adapun aspek-aspek tersebut yang dijadikan sebagai landasan antara lain aspek filosofis, aspek sosiologis, dan aspek yuridis, dapat dilihat dalam 
susunan Naskah Akademik UU ITE yaitu sebagai berikut $:^{1}$

Landasan filosofis, UndangUndang selalu mengandung norma hukum yang diidealkan (ideal norms) oleh suatu masyarakat ke arah mana citacita luhur kehidupan bermasyarakat dan bernegara hendak diarahkan. Cita-cita luhur yang terkandung dalam landasan filosofis hendaklah mencerminkan cita-cita filosofis yang dianut oleh bangsa Indonesia sendiri. Landasan filosofis merupakan pertimbangan atau alasan yang menggambarkan bahwa peraturan yang dibentuk mempertimbangkan pandangan hidup, kesadaran, dan cita hukum yang meliputi suasana kebatinan serta falsafah bangsa Indonesia yang bersumber dari Pancasila dan Pembukaan Undang-Undang Dasar Negara Republik Indonesia Tahun 1945.

Landasan sosiologis, merupakan pertimbangan atau alasan yang menggambarkan bahwa peraturan yang dibentuk untuk memenuhi kebutuhan masyarakat dalam berbagai aspek. Landasan sosiologis sesungguhnya menyangkut fakta empiris mengenai perkembangan masalah dan kebutuhan masyarakat dan negara.

Landasan yuridis, merupakan pertimbangan atau alasan yang menggambarkan bahwa peraturan yang dibentuk untuk

mengatasi permasalahan
hukum atau mengisi
kekosongan hukum dengan
mempertimbangkan aturan
yang telah ada, yang akan
diubah, atau yang akan dicabut
guna menjamin kepastian
hukum dan rasa keadilan
masyarakat. Landasan yuridis
menyangkut persoalan hukum
yang berkaitan dengan
substansi atau materi yang
diatur sehingga dibentuk
Peraturan Perundang-undangan
yang baru. Beberapa persoalan
hukum itu, antara lain,
peraturan yang sudah
ketinggalan, peraturan yang
tidak harmonis atau tumpang
tindih, jenis peraturan yang
lebih rendah dari Undang-
Undang sehingga daya
berlakunya lemah,
peraturannya sudah ada tetapi
tidak memadai, atau
peraturannya memang belum
ada.

Akses-akses untuk

menyampaikan pendapat telah

didukung oleh sarana-sarana yang ada

di media elektronik yang tersambung

oleh internet, terlebih sarana tersebut

memberikan ruang publik bagi

seseorang untuk menyampaikan

pendapatnya. Dalam istilah umum,

media elektronik seringkali

diistilahkan sebagai media sosial, oleh

\footnotetext{
1 Naskah Akademik, Rancangan Undang-Undang Tentang Serah Simpan Karya Cetak dan Karya
}

Rekam, Dewan Perwakilan Rakyat Republik Indonesia Tahun 2017, h. 53-57. 
Jurnal Independent Fakultas Hukum

karena sifatnya yang sosial yaitu menghubungkan antar individu maupun kelompok dalam satu perangkat.

Sehubungan dengan hal itu, jika ditinjau dari pengguna media sosial yang terjadi di Indonesia maka berdasarkan riset Wearesosial Hootsuite yang dikutip oleh laman website katadata.co.id, sebagai berikut $:^{2}$

Berdasarkan hasil riset Wearesosial Hootsuite yang dirilis Januari 2019 pengguna media sosial di Indonesia mencapai 150 juta atau sebesar $56 \%$ dari total populasi. Jumlah tersebut naik $20 \%$ dari survei sebelumnya. Sementara pengguna media sosial mobile (gadget) mencapai 130 juta atau sekitar $48 \%$ dari populasi.

Besarnya populasi, pesatnya pertumbuhan pengguna internet dan telepon merupakan potensi bagi ekonomi digital nasional. Alhasil, muncul e-commerce, transportasi online, toko online dan bisnis lainnya berbasis internet di tanah air. Ini akan menjadi kekuatan ekonomi

\footnotetext{
${ }^{2}$ Data Pengguna Telepon, Internet, Media Sosial Indonesia Menurut Wearesosial (2019), https://databoks.katadata.co.id/datapublish/2019/02 /08/berapa-pengguna-media-sosial-indonesia, diakses 17 Desember 2019.
}

digital di kawasan Asia Tenggara.

Dari sudut pandang ekonomi memang menguntungkan terhadap nilai pertumbuhan ekonomi yang didukung oleh sarana-sarana internet, namun dari sudut pandang hukum pidana telah banyak kejahatankejahatan yang dilakukan di dalam media sosial, terlebih kejahatan yang sensitif untuk dilakukan ialah dalam bentuk ujaran kebencian yang dampaknya akan luas yaitu menuju pada perpecahan.

Pentingnya upaya preventif dalam menyikapi ujaran kebencian telah dilakukan oleh Pemerintah Kota Sukabumi Jawa Barat, sebagaimana diberitakan oleh republika melalui media elektronik yaitu sebagai berikut $:^{3}$

Beragam cara dilakukan untuk mencegah maraknya berita hoax dan ujaran kebencian di media sosial (Medsos). Salah

\footnotetext{
3 Agung Sasongko, Sukabumi Gencarkan Aksi Pencegahan Ujaran Kebencian, https://www.republika.co.id/berita/daerah/jawabarat/19/12/16/q2m2up313-sukabumi-gencarkanaksi-pencegahan-ujaran-kebencian, diakses 17 Desember 2019.
} 
satunya dilakukan Pemerintah

Kota Sukabumi yang

menggelar kegiatan

penyuluhan hukum tingkat

Kota Sukabumi dengan tema pencegahan ujaran kebencian dan penyebaran hoax di Hotel Maxone Kota Sukabumi Senin (16/12).

Upaya yang dilakukan oleh

Pemerintah Kota Sukabumi untuk mencegah maraknya berita hoax dan ujaran kebencian disebabkan oleh banyaknya pengguna internet atau sosial media yang tidak atau masih belum bijak untuk menggunakan sarana-sarana media sosial, oleh karenanya Pemerintah Kota Sukabumi menggelar kegiatan penyuluhan untuk memberikan edukasi terhadap masyarakat.

Lebih lanjut, menanggapi hal itu menurut Dida selaku Sekretaris Daerah Kota Sukabumi yang diwawancarai oleh wartawan republika, menyatakan sebagai berikut $:^{4}$

Ujaran kebencian dan berita hoaks mengancam persatuan dan kesatuan bangsa. Oleh karenanya kegiatan penyuluhan hukum ini sangat positif di tengah perkembangan teknologi informasi salah satunya medsos.

Penyuluhan yang diinisiasi Bagian Hukum Setda Kota Sukabumi dan dihadiri Asisten Daerah (Asda) Satu Setda Kota Sukabumi Andri Setiawan dinilai sangat relevan dengan persoalan kekinian. Terutama pencegahan ujaran kebencian dan berita hoaks dengan menghadirkan pembicara yang menguasai hukum seperti Pengadilan Negeri Sukabumi.

Sekarang ini sulit dibedakan mana berita yang benar dan yang masuk kriteria ujaran kebencian dan hoaks. Sehingga dengan kegiatan ini para aparatur sipil negara (ASN) dan mahasiswa memahami konsekuensi hukum ketika menyebarkan ujaran kebencian dan berita hoaks. Targetnya para peserta penyuluhan dapat menghindari ujaran kebencian dan berita hoaks.

Target penyuluhan yang digelar oleh Pemerintah Kota Sukabumi ialah Aparatur Sipil Negara (ASN) dan mahasiswa, dikarenakan kedua elemen tersebut diyakini sebagai motor penggerak dinamika sosial di lingkungan masyarakat. Selain itu juga dalam penyuluhan yang digelar, mengundang pembicara yang

\footnotetext{
${ }^{4}$ Ibid.
} 
Jurnal Independent Fakultas Hukum

menguasai aspek-aspek hukum, hal ini agar materi yang disampaikan lebih terang karena kompetensi yang dimiliki oleh pembicara.

Lebih lanjut menurut Dhian Fhebriandari selaku pihak pembicara kegiatan penyuluhan dari Pengadilan Negeri Sukabumi, sebagaimana dikutip oleh republika menyatakan sebagai berikut $:^{5}$

Masalah ujaran kebencian dan berita hoax diatur dalam sejumlah ketentuan.Terutama dalam KUHP dan UndangUndang tentang Informasi dan Transaksi Elektronik (ITE).

Sudah selayaknya masyarakat berhati-hati dengan hal tersebut. Khususnya menjaga etika ketika membuat konten di media sosial.

Poin penting yang disampaikan

oleh Dhian Fhebriandari selaku pembicara kegiatan penyuluhan yang digelar oleh Pemerintah Kota Sukabumi, yaitu hukum dan etika. Poin pertama, hukum yaitu atas perbuatan hoax dan ujaran kebencian haruslah ditinjau dari KUHP dan UU ITE.
Sedangkan poin kedua, etika yaitu dapat berupa norma-norma yang berlaku di masyarakat atau dengan kata lain nilai-nilai adat/kebiasaan yang berlaku kuat di masyarakat.

Tinjauan atas perbuatan hoax dan ujaran kebencian didasarkan pada KUHP dan UU ITE, sebagaimana dalam dua substansi hukum (KUHP dan UU ITE) tersebut apabila didasarkan pada perspektif hukum pidana ialah yang menjadi kunci perbuatan itu dapat dipidana atau tidak tergantung pada pemenuhan unsur sifat melawan hukum. Karena apabila tidak terpenuhinya sifat melawan hukum, maka tidak dapat dinilai sebagai tindak pidana menurut ketentuan undangundang yang berlaku.

Selanjutnya sehubungan dengan kasus ujaran kebencian di lingkungan Aparatur Sipil Negara (ASN), Pelaksana tugas (Plt) Kepala Badan Pembinaan Ideologi Pancasila

\footnotetext{
${ }^{5}$ Ibid.
} 
(BPIP) Hariyono dikutip oleh laman

berita kompas.com menyatakan

sebagai berikut $:^{6}$

Saat ini masih ada Aparatur Sipil Negara (ASN) di Kementrian atau lembaga negara yang menyebarkan ujaran kebencian meski sudah berkali-kali diingatkan oleh atasannya.

Selama ini banyak pimpinan dan atasan langsung sudah mengingatkan. Sehingga kalau melihat data dalam diskusi kami, dengan beberapa pejabat tinggi itu, sudah diingatkan pun (ASN) masih tidak mampu mengurangi kebiasaan (menyebarkan) ujaran kebencian.

Pemerintah perlu bertindak tegas terhadap ASN yang masih menyebar ujaran kebencian dan terpapar radikalisme kendati sudah diperingatkan.

ASN terutama di medsos itu masih suka mengumbar ujaran kebencian, bahkan mencaci maki pimpinan maupun lembaga negara. Kan ironis. Nah inilah yang ingin kita tertibkan.

Selain itu, Badan Intelijen Negara (BIN), Badan Nasional Penanggulangan Terorisme (BNPT), Badan Kepegawaian Negara, Badan Pembinaan Ideologi Pancasila (BPIP), dan Komisi Aparatur Sipil Negara. Salah satu poin yang tak boleh dilanggar ASN adalah memberikan pendapat lisan maupun tulisan di media sosial yang bermuatan ujaran

\footnotetext{
${ }^{6}$ Kristian Erdianto, BPIP : Masih Ada ASN yang Kebiasaan Menyebarkan Ujaran Kebencian, https://nasional.kompas.com/read/2019/11/25/2024
}

kebencian terhadap Pancasila, UUD 1945, Bhinneka Tunggal Ika, NKRI, dan pemerintah. "Maka harus ada tindakan yang tegas sesuai peraturan perundang-undangan.

Aparatur Sipil Negara (ASN)

sebagai publik figur seyogyanya dapat memberikan contoh yang baik kepada masyarakat, apalagi kasus ujaran kebencian seharusnya tidak menjadi kebiasaan ASN sebagai struktur lembaga negara. Untuk waktu ke depan, perbaikan integritas ASN terhadap perbuatan ujaran kebencian di media sosial mampu memberikan dampak yang positif terhadap masyarakat serta memberikan contoh yang baik pula kepada masyarakat.

\section{METODE PENELITIAN}

Type penelitian yang digunakan penulis dalam penelitian ini adalah yuridis normatif, metode penelitian yuridis normatif adalah suatu prosedur penelitian ilmiah untuk menemukan kebenaran 4241/bpip-masih-ada-asn-yang-kebiasaanmenyebarkan-ujaran-kebencian?page=all, diakses 18 Desember 2019. 
Jurnal Independent Fakultas Hukum

berdasarkan logika hukum dari sisi normatifnya. ${ }^{7}$

Oleh karena itu penelitian hukum ini berfokus pada kajian penelitan hukum tentang kaidahkaidah atau norma-norma dalam hukum positif, yaitu norma-norma atau aturan-aturan hukum yang berkaitan dengan masalah perbuatan hoaks dan ujaran kebencian di media sosial.

Dalam penelitian ini menggunakan pendekatan perundang-undangan (statute approach) dan pendekatan konseptual (conceptual approach).

Pendekatan UndangUndang (Statute Approach) adalah dilakukan dengan menelaah semua Undang-Undang dan regulasi yang berkaitan dengan isu dan permasalahan-permasalahan hukum yang sedang ditangani. ${ }^{8}$

Sedangkan pendekatan konseptual (conceptual approach) adalah pendekatan ini beranjak dari pandangan-pandangan dan doktrin-doktrin yang berkembang di dalam Ilmu Hukum.

Sumber bahan hukum yang digunakan meliputi, bahan hukum primer dan bahan hukum sekunder. Bahan hukum primer terdiri dari perundang-undangan, yaitu :

1) Bahan hukum primer merupakan bahan hukum yang bersifat autoratif, artinya bahan hukum tersebut mempunyai otoritas. ${ }^{9}$ Adapun bahan hukum primer yang digunakan dalam penelitian ini adalah:
${ }^{7}$ Johnny Ibrahim, Teori \& Metode Penelitian Hukum Normatif. Bannyumedia Publishing, Malang 2006, h. 57.

8 Zulfi Diane Zaini, Implementasi Pendekatan Yuridis Normatif Dan Pendekatan Normatif
Sosiologis Dalam Penelitian Hukum, Pranata Hukum, Volume 6 Nomor 2 Juli 2011, hlm 129.

${ }^{9}$ Ibid. h. 181 . 
Jurnal Independent Fakultas Hukum

a. Undang-Undang Dasar

Negara Republik Indonesia

Tahun 1945;

b. Kitab

Undang-Undang

Hukum Pidana (KUHP);

c. Undang-Undang Nomor 19

Tahun 2016jo Undang-

Undang Nomor 19 Tahun

2016 Tentang ITE (Informasi

dan Transaksi Elektronik).

2) Bahan Hukum Sekunder

Bahan hukum sekunder

berguna untuk memberikan

kepada peneliti semacam

petunjuk kearah mana peneliti

akan melangkah, sebagai

inspirasi bagi peneliti untuk

menjadi titik anjak dalam

memulain penelitian. ${ }^{10}$ Adapun

bahan hukum sekunder dalam

penelitian ini adalah:

1. buku-buku hukum

2. jurnal-jurnal hukum
${ }^{10}$ Ibid. h. 196.

11 ANT/YOZ, Pikir Ulang Bila Mau Sebarkan Berita Bohong, Ini Peringatan dari Polisi, Berita Utama,https://www.hukumonline.com/berita/baca/l
3. pendapat dan hasil karya ilmiah para sarjana

4. internet dengan

menyebutkan nama situsnya.

\section{TINDAK PIDANA HOAX DAN UJARAN KEBENCIAN DALAM HUKUM PIDANA}

Lebih lanjut mengenai persoalan perbuatan hoax dan ujaran kebencian, telah diperingatkan sebelumnya oleh pihak kepolisian sebagaimana dijelaskan dalam artikel hukumonline.com yang berjudul "Pikir Ulang Bila Mau Sebarkan Berita Bohong, Ini Peringatan dari Polisi” yang juga mengutip pernyataan Kepala Biro Penerangan Masyarakat (Karopenmas) Polri Kombes Pol Rikwanto dalam pesan singkat diterima di Jakarta, yaitu sebagai berikut $:^{11}$

Kepolisian Republik Indonesia meminta masyarakat tidak

t5831c22d07ea8/pikir-ulang-bila-mau-sebarkanberita-bohong--ini-peringatan-daripolisi?utm_source=dlvr.it/, 08 Januari 2020. 
langsung mempercayai dan menyebarkan pesan berantai melalui perangkat elektronik karena bila ternyata pesan tersebut tidak benar, bohong, maka penyebarnya bisa dikenai sanksi pidana.

Menurut Kepala Biro Penerangan Masyarakat (Karopenmas) Polri Kombes Pol Rikwanto, menyatakan bahwa bagi Anda yang suka mengirimkan kabar bohong (hoax), atau bahkan sekedar iseng mendistribusikan (forward), harap berhati-hati. Ancamannya tidak main-main, bisa kena pidana penjara enam tahun dan denda Rp 1 milliar. Pelaku penyebar kabar atau berita bohong bisa dianggap melanggar Pasal 28 Ayat 1 dalam Undang-Undang Informasi dan Transaksi Elektronik (UU ITE).

Jadi, setiap orang harus berhatihati dalam menyebarkan pesan berantai lewat perangkat elektronik. Sekarang banyak SMS, maupun surat elektronik (email) hoax yang berseliweran.

Walaupun peringatan yang disampaikan oleh Kombes Pol Rikwanto disampaikan sejak tahun 2016 lalu, namun perkembangan motif penggunaan media elektronik internet semakin berubah secara dinamis yang
12 Abi Jam'an Kurnia, Jerat Hukum Penyebar Ujaran Kebencian di YouTube, Klinik: Telekomunikasi\&Teknologi,https://www.hukumon mengarahkan pada perbuatan hoaks dan ujaran kebencian.

Berkaitan dengan hal itu, perlu diketahui bahwa konten youtube telah banyak diakses oleh sebagian besar masyarakat Indonesia. Berkenaan dengan perbuatan ujaran kebencian melalui youtube telah dijelaskan oleh Abi Jam'an Kurnia, S.H dalam artikel yang dimuat oleh situs resmi hukumonline.com yang berjudul "Jerat Hukum Penyebar Ujaran Kebencian di Youtube", yaitu sebagai berikut $:^{12}$

Diakses melalui laman Kebijakan Youtube, berikut adalah kebijakan terkait ujaran kebencian untuk platform YouTube :

Kami mendukung kebebasan berbicara dan membela hak Anda untuk menyatakan pandangan yang tidak populer. Namun, kami melarang ujaran kebencian.

Perkataan yang mendorong kebencian mengacu pada konten yang menyerukan kekerasan atau bertujuan untuk menghasut kebencian terhadap individu atau kelompok berdasarkan atribut tertentu, seperti :

- Ras atau etnis asal

- Agama

line.com/klinik/detail/ulasan/lt584a704d611dc/jerat -hukum-penyebar-ujaran-kebencian-di-youtube, diakses 08 Januari 2020. 
- Disabilitas

- Jenis kelamin

- Usia

- Status veteran

- Orientasi seksual/identitas gender

Ada garis tipis antara mana yang dianggap sebagai ujaran kebencian dan mana yang bukan. Misalnya, konten yang mengkritik negara suatu bangsa secara umum tidak dilarang. Namun, jika tujuan utama konten tersebut adalah untuk menghasut kebencian terhadap sekelompok orang semata-mata berdasarkan etnis mereka, atau jika konten tersebut menyerukan kekerasan atas dasar salah satu atribut utama, seperti agama, maka konten tersebut melanggar kebijakan kami.

Berdasarkan hal tersebut, terdapat beberapa aspek/atribut yang disebutkan dalam Kebijakan YouTube, yang nyatanya juga terdapat dalam Surat Edaran Kepala Kepolisian Negara Republik Indonesia Nomor SE/6/X/2015 Tahun 2015 tentang Penanganan Ujaran Kebencian (Hate Speech) ("SE KAPOLRI 6/2015").

Secara esensi penghinaan, pencemaran nama baik merupakan perbuatan menyerang kehormatan atau nama baik seseorang, sehingga nama baik orang tersebut tercemar atau rusak. Dalam menentukan adanya penghinaan atau pencemaran nama baik, konten dan konteks menjadi bagian yang sangat penting untuk dipahami. Tercemarnya atau rusaknya nama baik seseorang secara hakiki hanya dapat dinilai oleh orang yang bersangkutan.
Dengan kata lain, korbanlah yang dapat menilai secara subyektif tentang konten atau bagian mana dari informasi atau dokumen elektronik yang ia rasa telah menyerang kehormatan atau nama baiknya. Itu artinya, perkataan seperti 'brengsek' yang diucapkan atau perbuatan lain yang termasuk ujaran kebencian yang disebarkan di media YouTube hanya dapat dinilai oleh korban yang bersangkutan apakah mencemarkan, menghina, dan/atau merusak nama baiknya.

Berdasarkan penjelasan yang panjang lebar di atas, ujaran kebencian (hate speech) khususnya dalam platform YouTube yang diakses oleh sebagian besar masyarakat di Indonesia pada dasarnya telah memiliki kebijakan tersendiri terkait perbuatan ujaran kebencian dalam platformnya. Adapun kebijakan tersebut, pada kenyataannya selaras dengan Surat Edaran Kepala Kepolisian Negara Republik Indonesia Nomor SE/6/X/2015 Tahun 2015 tentang Penanganan Ujaran Kebencian (Hate Speech).

$$
\text { Adanya regulasi yang }
$$

memberikan ancaman terhadap 
perbuatan ujaran kebencian melalui media elektronik internet, lebih lanjut diperkuat lagi oleh pernyataan Kepala Biro Penerangan Masyarakat Divisi Humas Polri Brigjen Rikwanto melalui situs resmi kominfo.go.id, menyatakan sebagai berikut $:^{13}$

Orang yang menebarkan informasi palsu atau hoax di dunia maya akan dikenakan hukum positif. Hukum positif yang dimaksud adalah hukum yang berlaku. Maka, penebar hoax akan dikenakan KUHP, Undang-Undang No. 19 Tahun 2016tentang Informasi dan Transaksi Elektronik (ITE), Undang-Undang No. 40 Tahun 2008 tentang Penghapusan Diskriminasi Ras dan Etnis, serta tindakan ketika ujaran kebencian telah menyebabkan terjadinya konflik sosial.

Penebar hoax di dunia maya juga bisa dikenakan ujaran kebencian yang telah diatur dalam KUHP dan UU lain di luar KUHP. Ujaran kebencian ini meliputi penghinaan, pencemaran nama baik, penistaan, perbuatan tidak menyenangkan,

memprovokasi, menghasut, dan penyebaran berita bohong. Jadi, hoax ini harus ada yang dirugikan, baik itu seseorang atau korporasi yang merasa dirugikan. Ujaran kebencian ini biasanya bertujuan untuk menghasut dan menyulut

${ }^{13}$ Diandra, Penebar Hoax Bisa Dijerat Segudang Pasal, Kategori Sorotan Media, https://kominfo.go.id/content/detail/8863/penebar- kebencian terhadap individu dan/atau kelompok masyarakat, antara lain suku, agama, aliran keagamaan,

keyakinan/kepercayaan, ras, antar golongan, warna kulit, etnis, gender, kaum difabel, hingga orientasi seksual.

Ujaran kebencian atau hate speech ini dapat dilakukan dalam bentuk orasi kampanye, spanduk, jejaring media sosial, penyampaian pendapat di muka umum, ceramah keagamaan, media massa cetak maupun elektronik, sampai pamflet.

Sehubungan dengan itu, mengenai sifat melawan hukumnya perbuatan hoax dan ujaran kebencian yang dilakukan di dalam media elektronik yang terhubung dengan internet, sebagaimana dipaparkan oleh Anna Puji Lestari, M.I.Kom selaku Dosen pengampu mata kuliah Ilmu Komunikasi Universitas Islam Negeri Walisongo Semarang dalam artikel berita elektronik yang dimuat dalam situs berita antaranews.com yang berjudul "Ujaran Kebencian dan Gangguan Komunikasi” mengutip dari pernyataan Susan Benesch (dalam

hoax-bisa-dijerat-segudang-pasal/0/sorotan_media, diakses 08 Januari 2020. 


\begin{abstract}
Anam dan Hafiz, 2015) yang menanggapi permasalahanpermasalahan terkait perbuatan hoax dan ujaran kebencian yang terjadi sepanjang tahun 2019 sekaligus memaparkan sejumlah instrumen internasional dan hukum positif terkait ujaran kebencian, yaitu sebagai berikut $:^{14}$
\end{abstract}

Menurut Susan Benesch, jika ujaran tersebut dapat menginspirasi orang lain untuk melakukan kekerasan, menyakiti orang atau kelompok lain maka ujaran kebencian itu berhasil dilakukan.

Terdapat sejumlah instrumen internasional berkenaan dengan pelarangan ujaran kebencian, seperti: Deklarasi HAM PBB 1948; Konvensi Internasional Tentang Penghapusan Segala Bentuk Diskriminasi Rasial (Convention On The Elimination Of All Forms of Racial Discrimination/CERD); dan Konvenan Internasional tentang Hak Sipil dan Politik (International Convenant on Civil and Political Rights/ICCPR).

Selain itu, UU No. 19 Tahun 2016sebagaimana telah diubah dengan UU No. 19 Tahun 2016 tentang Informasi dan Transaksi Elektronik (UU ITE), juga memuat larangan dan ancaman pidana bagi pelaku

14 Anna Puji Lestari, Ujaran Kebencian dan Gangguan Komunikasi, Copyright Antara, Jakarta, 2019, yang membuat ujaran kebencian ataupun berita bohong.

Pasal 28 Ayat (1) jo Pasal 45 UU ini memuat ancaman pidana bagi setiap orang dengan sengaja dan tanpa hak menyebarkan berita bohong dan menyesatkan, yang mengakibatkan kerugian konsumen dalam transaksi elektronik. Tindak pidana ini dirumuskan secara materiil. Artinya, tindak pidana tersebut selesai sempurna bila akibat perbuatan telah timbul yaitu adanya kerugian konsumen dalam transaksi elektronik.

Selain itu, pelaku juga mengerti bahwa apa yang dilakukannya itu tidak dibenarkan (sifat melawan hukum subjektif) dan mengerti akan mengakibatkan kerugian bagi konsumen transaksi elektronik.

Terhadap perbuatan hoaks dan ujaran kebencian tidak hanya diatur oleh hukum positif (hukum yang berlaku di Indonesia) saja, namun juga diatur oleh perjanjian/konvensi internasional. Sedangkan unsur dari perbuatan hoax dan ujaran kebencian termasuk dalam kategori sifat melawan hukum yang mana dalam hukum pidana juga dibenarkan hal tersebut berdasarkan peraturan perundang-

https://www.antaranews.com/berita/809833/ujarankebencian-dan-gangguan-komunikasi, diakses 08 Januari 2020. 
Jurnal Independent Fakultas Hukum

undangan pidana yang berlaku

terhadap perbuatan hoax dan ujaran

kebencian. Dari penjelasan di atas,

Brigjen Rikwanto menuturkan adanya

beberapa peraturan hukum yang dapat

menjerat perbuatan hoax maupun

ujaran kebencian serta menjelaskan

harus adanya korban atau pihak yang

merasa dicemarkan nama baiknya dari

perbuatan hoax atau ujaran kebencian

berdasarkan penilaian subyektifnya.

\section{PENUTUP}

Dari pemaparan di atas,

terhadap perbuatan hoaks dan ujaran

kebencian tidak hanya diatur oleh

hukum positif (hukum yang berlaku di

Indonesia) saja, namun juga diatur oleh

perjanjian/konvensi internasional.

Sedangkan unsur dari perbuatan hoax

dan ujaran kebencian termasuk dalam

kategori sifat melawan hukum yang

mana dalam hukum pidana juga

dibenarkan hal tersebut berdasarkan

peraturan perundang-undangan pidana

yang berlaku terhadap perbuatan hoax

dan ujaran kebencian.

\section{REFERENSI}

A. BUKU

Andi Sofyan \& Nur Azisa, Buku Ajar Hukum Pidana, Cetakan Kesatu, Pustaka Pena Press, Makassar, 2016.

Mokhammad Najih \& Soimin, Pengantar Hukum Indonesia (Sejarah, Konsep Tata Hukum, dan Politik Hukum Indonesia), Edisi Revisi, Cetakan Kelima, Setara Press, Malang, 2016.

Tongat, 2012, Dasar-Dasar Hukum Pidana Dalam Perspektif Pembaharuan, UMM Press, Cetakan Ketiga, Malang.

Zulfi Diane Zaini, Implementasi Pendekatan Yuridis Normatif Dan Pendekatan Normatif Sosiologis Dalam Penelitian Hukum, Pranata Hukum, Volume 6 Nomor 2 Juli 2011, hlm 129.

\section{A. Peraturan Perundang-Undangan}

Undang-Undang Dasar Negara Republik Indonesia Tahun 1945;

Kitab Undang-Undang Hukum Pidana (KUHP);

Undang-Undang Nomor 19 Tahun 2016jo Undang-Undang Nomor 19 Tahun 2016 Tentang ITE (Informasi dan Transaksi Elektronik).

\section{B. Internet}

Abi Jam'an Kurnia, Jerat Hukum Penyebar Ujaran Kebencian di YouTube, Klinik:

Telekomunikasi \& Teknologi, https://www.hukumonline.com /klinik/detail/ulasan/lt584a704 d611dc/jerat-hukum-penyebarujaran-kebencian-di-youtube, diakses 08 Januari 2020.

Agung Sasongko, Sukabumi Gencarkan Aksi Pencegahan Ujaran Kebencian, https://www.republika.co.id/be rita/daerah/jawabarat/19/12/16/ q2m2up313-sukabumigencarkan-aksi-pencegahan- 
ujaran-kebencian, diakses 17 Desember 2019.

Anna Puji Lestari, Ujaran Kebencian dan Gangguan Komunikasi, Copyright Antara, Jakarta, 2019,

https://www.antaranews.com/b erita/809833/ujaran-kebenciandan-gangguan-komunikasi, diakses 08 Januari 2020.

ANT/YOZ, Pikir Ulang Bila Mau Sebarkan Berita Bohong, Ini Peringatan dari Polisi, Berita Utama https://www.hukumonline.com /berita/baca/1t5831c22d07ea8/ pikir-ulang-bila-mau-sebarkanberita-bohong--ini-peringatandaripolisi?utm_source $=$ dlvr.it/, diakses 08 Januari 2020.

Data Pengguna Telepon, Internet, Media Sosial Indonesia Menurut Wearesosial (2019), https://databoks.katadata.co.id/ datapublish/2019/02/08/berapa -pengguna-media-sosialindonesia, diakses 17 Desember 2019.

Diandra, Penebar Hoax Bisa Dijerat Segudang Pasal, Kategori Sorotan Media, https://kominfo.go.id/content/d etail/8863/penebar-hoax-bisadijerat-segudangpasal/0/sorotan_media, diakses 08 Januari 2020.

Kristian Erdianto, BPIP : Masih Ada ASN yang Kebiasaan Menyebarkan Ujaran Kebencian, https://nasional.kompas.com/re ad/2019/11/25/20244241/bpipmasih-ada-asn-yangkebiasaan-menyebarkanujaran-kebencian?page $=$ all, diakses 18 Desember 2019. 